\title{
Successor to the World Conservation Strategy
}

IUCN, WWF, and UNEP, are supporting the preparation of a successor to the World Conservation Strategy, to be published early in 1991. The successor will build on the World Conservation Strategy prepared in 1980, and will adapt and extend its proposals to meet the challenges of the coming decade.

While the original World Conservation Strategy (WCS) laid particular emphasis on the need to conserve the Earth's major ecobiomes and ecosystems as resources vital to the human future, the perspective for the 1990 s is very much one of guiding processes of development in human societies in such a manner as to achieve an enduring harmony with the natural world. The new text will therefore emphasize such issues as the nature of sustainable development, the achievement of stable human populations, the value of the experience of indigenous and traditional societies, the central role of women in environmental management, and the need for a new approach to economic evaluation of natural resources.

The Project Director of the new Strategy is the undersigned, who, as the then Director-General of IUCN, guided the preparation of the 1980 WCS, and the Writer-Senior Consultant is Mr Robert Prescott-Allen, who, as Robert Allen, wrote the final text of the original Strategy. A preliminary draft of the new strategy has been prepared, which it is intended to expose to the widest possible discussion among conservationists and others, with due development of the main themes through special workshops in different parts of the world. A revised text will be discussed at the IUCN General Assembly in November 1990.

Requests for copies of the preliminary draft should be addressed to the undersigned, and will be furnished on the strict understanding that no publication of the strategy or any part thereof may be undertaken at this stage without the specific permission of IUCN or the undersigned acting on its behalf.
David A. MunRo
clo IUCN, The World Conservation Union Avenue du Mont-Blanc
1196 Gland
Switzerland.

\section{Acceptance Speech of the 33rd Annual WMO Prize by Our Foundation's Hon. Secretary}

I am deeply touched, and at the same time humbled and gratified, at being thus honoured by the World Meteorological Organization. This is a body which, I like to think, fulfils its key part of the mandate of the UN more fully than any other-and was indeed doing so under other names before the UN existed. It is not that we meteorologists and climatologists are morally superior to our fellows. It is simply that we cannot do our work without effective international accord. And so, for well over a century, we have been quietly doing what the whole community of nations strives for and does not always achieve: a common effort for the benefit of all.

It is a special honour to receive this award in the presence of the Secretary General. Thirty years ago he was briefly my student, and then my young colleague in the stratospheric analysis group at Dorval, near Montreal. Christopher Abayomi was another one of us. Their careers since then have been distinguished. There have been times when all of us must have wished that we were still drawing 25-millibar charts at Dorval. But we have faced up to the need to do things in the wider world. I hope that the Secretary General will continue along this path for a long time. In my own case, I hope to be put out to grass, though not too soon.

It is also an honour to receive this award in the presence of the PR of Canada in WMO, Howard Ferguson, my longtime friend and research colleague. I have been very lucky to receive over the past thirty years the unstinting support of governmental colleagues-James Bruce, Arthur Collin (another former student), Reginald Noble, Patrick McTaggart-Cowan, and Andrew Thomson. They have been, as have other familiar figures in WMO-Morley Thomas, Gordon McKay, Edward Munn, Byron W. Boville, Warren Godson, and Svenn Orvig-close friends. The myth has it that public servants and professors cannot get along. In Canada that is happily untrue: relations have been excellent.

Looking back on a long life, I see how much I have owed to others. Weather was my passion from earliest childhood, when I ran a weather station; but I was a naturalist, not a scientist - a bird's nester, not a researcher. Then I came progressively under the influence of extraordinary men who dragged me upwards: my old professors, Stamp and Wooldridge, and then (at Imperial College) David Brunt and Peter Sheppard: in the UK Meteorological Office,
Charles Durst and, more recently, John Mason. Outside it there was Howard Penman. In the post-war world I owed much to $\mathrm{C}$. Warren Thornthwaite who, as President of $\mathrm{C} . \mathrm{Cl}$, introduced me to WMO as an expert (I still carry a card so describing me from C.Cl II). Then there were Hermann Flohn and Reid Bryson, I must recall, who between them made climate a famous idea. And also my valued colleagues in the US (Tom Malone in particular) and the USSR (Mikhail Budyko, * who remade the surface heat and water balances).

From Finland, I learned much from that great ecologist, the late Ilmari Hustich. I have enjoyed the friendship of Gilbert F. White, Robert M. White, Yevgeny Fedorov, and Bert Bolin (whose perspective of our discipline parallels my own, though his widely overshadows mine). My close relations with UNEP - its distinguished Executive Directors Maurice Strong and Mostafa Tolba-and my old friend, C.C. Wallén, have also impelled me forward. We all ride on the shoulders of others, none more than I.

In my lifetime our science has become central to human welfare, and crucial to our preparations for the future. I was honoured to have had a hand in the planning of the First World Climate Conference, and look forward to being a spectator at the second. My vision of our field is one with no protective barriers around it. We should welcome the chemists, biologists, geographers, doctors, and economists. who now want to invade our territories. We can absorb them all, and be better scientists and public servants for having made a meal of them! And if the boot is on the other foot, to mix a metaphor, and we are ourselves absorbed into something larger, and we in our turn get eaten, that too we should welcome. What counts is the world's survival.

For much of the past ten years, indeed. I have been caught up in other affairs - the acid rain controversy, the nuclear winter affair, the problem of lead in the environment, the aftermath of the nuclear accident at Chernobyl (the latter also involving, I know, my colleague, Yuri Izrael). In all these cases the atmospheric scientist played a crucial role, but could not hope to reach a conclusion without the help of others.

[Concluded on page 270]

* Recipient of this unique award last year-see Environmental Conservation, 15(2), p. 181, 1988.-Ed. 